\title{
Evaluation of Potential Effect of Enriched-Chestnut Yoghurt on Rats with Hyperthyroidism Induced by L-Thyroxine
}

\author{
Abeer Elsayed Elkhamisy \\ Assistant Professor of Nutrition and Food Science \\ Faculty of Specific Education, Home Economics Dept., \\ Port Said University, Egypt.
}

\begin{abstract}
With growing interest in using alternative and complementary medicine, especially medicinal plants, because of low cost and less adverse effects. This study was performed to evaluate the anti-hyperthyroidism effects of medicinal herb, chestnut (Castanea sativa mill) that used to enrich yoghurt with different premixes on levothyroxine (LT4)-induced hyperthyroidism rats. Male wistar rats were divided into seven groups five each, namely, normal group (-ve), hyperthyroidism control group (+ve), hyperthyroidism plus PTU as treated with standard drug, hyperthyroidism plus enriched-chestnut yoghurt prepared with chestnut by cow milk $\left(\mathrm{T}_{1}\right)$, hyperthyroidism plus enriched-chestnut yoghurt prepared with chestnut by blending cow milk [1:1] $\left(\mathrm{T}_{2}\right)$, hyperthyroidism plus enriched-chestnut yoghurt prepared with chestnut by blending cow milk at [3:1] $\left(\mathrm{T}_{3}\right)$ and hyperthyroidism plus enriched-chestnut yoghurt prepared with chestnut by blending cow milk at [6:1] $\left(\mathrm{T}_{4}\right)$, rats in all groups except normal were injected with LT4 for 2 weeks to induce hyperthyroidism and then were administrated each treatment for 6 weeks. Biomarkers linked to hyperthyroidism were determined. Results, showed that, serum TC, TG, LDLc, VLDL-c, Urea Nitrogen, AST, ALT, Triiodothyronine and Thyroxine, meanwhile, were significantly reduced in $\mathrm{T}_{3}, \mathrm{~T}_{4}$ and PTU groups compared with the hyperthyroidism (+ve) group. Meanwhile, Serum HDL-c, uric acid, creatinine, and TSH were significantly increased in the enriched-chestnut yoghurt with different premixes and PTU groups. Results suggest that chestnut might suppress different biomarkers, Triiodothyronine, Thyroxine and TSH activities by modulating their concentrations and therefore, enriched yoghurt with chestnut could be an alternative therapy for hyperthyroidism.
\end{abstract}

Key Words: chestnut, Hyperthyroidism, Liver functions, PH, Thyroid hormones 


\section{Introduction}

Plants and their corresponding potential preparations have been used from old civilizations owing to their remarkable botanical in both prevention and treatment of oxidative stress and its complications. These plants attracted the attention owe to the inherent antioxidant activity of the bioactive that decrease the free radical induced oxidative damage. Consumption of various plants parts that have high amounts of phenolic compounds is vital to protect from oxidative damage (Salehi et al., 2020). Sweet Chestnut (Castanea sativa mill) belongs to the family Fagaceae, and generally cultivate all through the clement countries (Pandey et al., 2018). There is growing evidence showing that the consumption of chestnut has become more vital for human nutrition and prompting health benefits. The chestnut considered as rich source of fiber, unsaturated fatty acids, protein, starch, vitamins, minerals and different bioactive constituents that promoting health (Muzaffar and Maqbool 2016 and Oniszczuk et al., 2019). Chestnut has been popularly used in folk medicine for treatment of different respiratory disorders and recent literatures have displayed that the Castanea sativa possesses cardioprotective (Chiarini $\boldsymbol{e t}$ al., 2013), antimicrobial (Jukic and Trutic 2014), neuroprotective (Santulli et al., 2017), anti-obesity complication (Budriesi et al., 2018) and antioxidant activities (Pandey $\boldsymbol{e}$ ( $\boldsymbol{a l} ., 2018$ ) as well as the ability to prevent DNA damage (Lenzi et al., 2017).

Since, yoghurt is commercially obtainable in various kinds and is highly valued for ease of consumption as fermented dairy food and its sensory properties (Gao et al., 2018). Even though yogurt contains different health promoting constituents, it stills a poor source of phytochemical components. Nowadays, there is a popular approach to enhance phenolic components of the yoghurt and likewise improve antioxidant profile by adding fresh or processed fruits in yogurt and dairy products. At the same time, using supplementation of natural antioxidant sources in yogurt also meets the consumer demands for "clean label" foods (Granato et al., 2017 and Raikos et al., 2019).

On the other hand, thyroid hormones have a key role in metabolism, development, growth and thermoregulation such as triiodothyronine (T3) and thyroxine (T4) are tyrosine based hormones and thyroid glands are responsible for production and metabolism regulation (Kim and Lee 2019). Hyperthyroidism is a non-balanced of thyrotoxicosis and considered as metabolic condition caused by overproduction of thyroid hormone in the thyroid gland (De Leo et al., 2016). The main purpose of this work was to investigate the potential effect of chestnut enriched-yoghurt with different premixes on thyroid function in L-thyroxin receiving rats. 


\section{Materials and methods}

\section{Materials:}

Chestnut Edulis (Castanea Sativa Mill ) were obtained from local market and cut in small pieces. Commercially yoghurt cultures were purchased from Chr. Hansen, Laborotories, Capenhage, Denmark. Cow milk and fresh sweet water: cow milk [1:1] were obtained from Food Technology Research Institute, Agricultural Research Center, Giza, Egypt.

Drugs: Thiouracil (4-Hydroxy-2-mercapto-6-methylpyrimidine) and L-thyroxin ${ }^{\odot}$ Thiouracil were products of Sanofi- Synthelabo Company, Paris, France.

\section{Methods:}

Enrichment Combination of yoghurt: four treatment of yoghurt formulated to contain:

$\mathrm{YC}_{1}$ : Yoghurt prepared by cow milk

EC $_{2}$ : Yoghurt prepared by blending cow milk: cow milk [1:1]

$\mathbf{E C}_{3}$ : Yoghurt prepared by blending cow milk: cow milk [3:1]

EC $_{4}$ : Yoghurt prepared by blending cow milk: cow milk [6:1]

Each premix also contained 3\% sucrose and $0.5 \%$ gelatin, all premixes were homogenized at $85{ }^{\circ} \mathrm{C}$ for $10 \mathrm{~min}$ and then cooled to $45{ }^{\circ} \mathrm{C}$ as described by (Collins et al., 1991). Commercial yoghurt culture (1\%) Direct Vat Set (DVS) of streptococcus thermophillus and Lactobacillus delbrueckii sub sp. Bulgaricus of the milk volume was added (Lee et al., 1990). The milk mixture was placed in $250 \mathrm{ml}$ cups and kept in an incubator at $45^{\circ} \mathrm{C}$ for 3-6 h, and then the cups were transferred to refrigerator.

\section{Proximate composition:}

Yoghurt enrichment were analyzed for moisture, protein, lipid and ash content using standard methods (A.A.C.C., 2000). Total carbohydrate content was determined by difference. The $\mathrm{pH}$ was determined using a $\mathrm{pH}$ meter while acidity was measured as describe by (Osundahunsi et al., 2007).

\section{Animals and diets:}

The study was performed on male albino rat's weight between 120-140 g. The animals were obtained from Laboratory of Animal Colony, Helwan, Egypt. Rats were fed the basal diet for 7 days before the beginning of the experiment for adaptation. The standard diet comprised of prepared according to (Reeves $\boldsymbol{e t}$ al., 1993), diet and water were provided ad libitum. 


\section{Experimental design:}

After adaptation period the animals were randomly divided into 7 groups of 5 rats each and one of them was kept as a normal (-ve) control group. Rats were injected intraperitoneally with L-thyroxin drug at a dose of $0.5 \mathrm{mg} / \mathrm{kg}$ for 15 days to induce hyperthyroidism by the method used by (Davidson et al., 1978). LT4 group was kept as a positive (+ve) control group and rats in group (G4-G7) were orally administrated at a dose of $2 \mathrm{ml}$ yoghurt/rat/day by gavage for six weeks. The composition of these groups shows as follows:

Group (3) LT4 + PTU: Fed on basal diet and administrated with 6-n-propyl-2thiouracil (PTU, $10 \mathrm{mg} / \mathrm{kg}$ ) drug according to the previous established method (Saxena et al., 2012).

Group (4) LT4 + $\mathbf{T}_{1}$ : Fed on basal diet and $\mathbf{Y C}_{1}$ yoghurt

Group (5) LT4 $+\mathbf{T}_{2}$ : Fed on basal diet and $\mathrm{EC}_{2}$ yoghurt

Group (6) LT4 + T $\mathbf{T}_{3}$ : Fed on basal diet and yoghurt with premix $\mathrm{EC}_{3}$ : cow milk [3:1]

Group (7) LT4 $+\mathbf{T}_{4}$ : Fed on basal diet and yoghurt with premix EC 4 : cow milk [6:1]

\section{Biochemical evaluation:}

Serum aspartate aminotranalansferase (AST) and alanine amino transferase (ALT) concentrations were determined according to (Reitman and frankel 1957). Serum total cholesterol, triglycerides, high density lipoprotein and low density lipoprotein were determined by the methods of (Roeschlau et al., 1974 and Fossati and Prencipel 1982), respectively. Serum creatinine, uric acid and urea levels were determined according to (Bartles et al., 1972, Caraway, 1955 and Han et al., 1984), respectively. Serum levels of Triiodothyronine, Thyroxine and thyroid stimulating hormone (TSH) were analyzed by colorimetric competitive enzyme immunoassay using individual ELISA kit according to (Larsen, 1972, Schuurs and Van Weeman, 1997 and Bhowmich et al., 2007), respectively.

\section{Statistical analysis:}

Results are expressed as the mean standard deviation SD. Data were statistically analyzed of variance "ANOVA" test at $(\mathrm{P} \leq 0.05)$ according to (Vandallen, 1997), using SPSS statistical software, version 13.0 was used for these calculations.

\section{Results and Discussion}

\section{Physio-chemical composition of enriched-chestnut yoghurt}

The changes in physiochemical composition of enriched-chestnut with yoghurt are shown in Table 1. The moisture contents range from 86.82 to 88.61 .It can observed that the highest value of protein and fat were in $\mathrm{EC}_{4}(3.90$ and 3.79) containing yoghurt prepared by chestnut with water: cow milk at percent 
of [6:1], and the lowest values of protein and fat were found in $\mathrm{YC}_{1}(2.36$ and 1.58) containing yoghurt prepared by cow milk this may be owing to the addition of ingredients which are rich source of protein which eventually increased the level of protein in $\mathrm{EC}_{4}$. Meanwhile, highest value of carbohydrate was observed in $\mathbf{Y C}_{1}$ (8.59) contains yoghurt prepared by just chestnut with water and lowest value was observed in $\mathrm{EC}_{4}$ (3.66) contains yoghurt prepared by chestnut with water: cow milk at percent of [6:1]. Chestnut regarded as gluten free and its protein considered as a high quality protein comparable with eggs (Yadav et al., 2014). Furthermore, the elevation in protein and fat levels of enriched-chestnut yoghurts linked with addition of chestnut to yoghurt treatments (Singh et al., 2017).

$\mathrm{PH}$ values of enriched-chestnut yogurts were ranged from 2.34 to 4.79 . The YC 1 yoghurt cow milk had lower $\mathrm{pH}$ value than those of the cow milk addition. Using starter bacteria such as delbrueckii ssp. bulgaricus in a combination for production of yoghurt, it caused low $\mathrm{pH}$ and these low values of $\mathrm{pH}$ considered a harsh environment for the survival of probiotic organisms (Mohamed et al., 2017). The $\mathrm{pH}$ of yoghurts gradually increased, showing value of 4.79 in $\mathrm{T}_{4}$ and this is considered as a suitable $\mathrm{pH}$ degree for the yoghurt. Ozcan et al., (2017) reported that the addition chestnut in fermented dairy products stimulate the growth of probiotic bacteria and enhance its functionality. The total acidity of enriched-chestnut yoghurts ranged from 0.18 to 0.36 . The total acidity steadily increased because of the accumulation of lactic acid produced by lactic acid bacteria (Sengul et al., 2012). In addition, Oniszczuk et al., (2019) reported that chestnut considered as one of powerful plants with distinct taste and health-promoting properties.

Table 1: Physio-chemical composition of enriched-chestnut with yoghurt treated.

\begin{tabular}{ccccc}
\hline Parameters & $\mathbf{Y C}_{\mathbf{1}}$ & $\mathbf{E C}_{\mathbf{2}}$ & $\mathbf{E C ~}_{\mathbf{3}}$ & $\mathbf{E C}_{\mathbf{4}}$ \\
\hline Moisture \% & 86.82 & 87.47 & 88.61 & 88.21 \\
Protein \% & 2.36 & 2.85 & 3.96 & 3.90 \\
Fat \% & 1.58 & 2.29 & 2.53 & 3.79 \\
Ash\% & 0.69 & 0.67 & 0.86 & 0.66 \\
carbohydrate & 8.59 & 6.79 & 4.47 & 3.66 \\
PH & 2.34 & 3.08 & 3.54 & 4.79 \\
Total acidity & 0.18 & 0.24 & 0.25 & 0.36 \\
\hline
\end{tabular}

Data are expressed as mean, $\mathrm{n}=3$. $\mathbf{Y} \mathbf{C}_{1}$ : Yoghurt prepared by cow milk, $\mathbf{E C}_{2}$ : Yoghurt prepared by blending cow milk: cow milk [1:1], EC $\mathbf{E}_{3}$ : Yoghurt prepared by blending cow milk: cow milk [3:1], EC ${ }_{4}$ : Yoghurt prepared by blending cow milk: cow milk [6:1]

Changes on weight gain, feed intake and FER of control and Hyperthyroidism Rats.

The influence of continuously consuming enriched-chestnut yoghurt treatments with different premixes on health of hyperthyroidism rats was examined by measuring body weights each week (Table 2). There was a gradual decrease in body weight gain and feed intake of positive control group (+ve) by $79.10 \%$ and $22.30 \%$ when comparing with normal control group (-ve). However after consumption of enriched-chestnut yoghurts with different 
premixes $\left(T_{1}, T_{2}, T_{3}\right.$ and $\left.T_{4}\right)$ for 4 weeks, feed intake in normal control (-ve) and different treated groups (PTU, $\mathrm{T}_{1}, \mathrm{~T}_{2}, \mathrm{~T}_{3}$ and $+\mathrm{T}_{4}$ ) did not show differences in comparison with hyperthyroidism group $(+v e)$. Furthermore, weight gain of $\mathrm{T}_{1}$ and $\mathrm{T}_{2}$ groups was no different compared to the PTU which treated by antithyroid drug (Table 2). Comparing with the control group (-ve), there was a significant decrease in weight gain of the hyperthyroidism control group $(+v e)$ and $\mathrm{T}_{3}$ and $\mathrm{T}_{4}$ group $(P<0.05)$. These results supported by other finding of Khaled and Abul-Fadle (2017) who found a reduction in body weight with hyperthyroidism condition. Furthermore, Ríos-Prego et al., (2019) as they reported that thyroid dysfunctions associated by weight loss (gain) of rats. Hyperthyroidism has been linked with underweight and weight loss. Hyperthyroidism Subjects have an adrenergic hyper-stimulation with rises in thermogenesis and metabolism so, a greater overall energy expenditure which causing a tendency on weight loss. In addition, thyroid hormones dysfunction considered as major target which involved in the regulation of body weight (Gionfra et al., 2019).

Table 2: Changes on weight gain, feed intake and FER on hyperthyroidism rats groups in comparison to normal control group (-ve).

\begin{tabular}{cccccccc}
\hline Groups & $\begin{array}{c}\text { Weight gain } \\
(\mathbf{g})\end{array}$ & $\mathbf{\%}$ & $\begin{array}{c}\text { Feed intake } \\
\mathbf{( g / d )}\end{array}$ & $\mathbf{\%}$ & FER & \% \\
\hline Contr.(-ve) & $96.76 \pm 8.11 \mathrm{a}$ & - & $17.54 \pm 2.20 \mathrm{a}$ & - & $0.187 \pm 0.03 \mathrm{a}$ & - \\
Contr. (+ve) & $27.64 \pm 8.11 \mathrm{~d}$ & -79.10 & $14.34 \pm 2.20 \mathrm{~d}$ & -22.30 & $0.67 \pm 0.06 \mathrm{e}$ & +272.22 \\
PTU & $96.59 \pm 6.11 \mathrm{c}$ & -1.18 & $17.90 \pm 2.03 \mathrm{a}$ & -0.78 & $0.182 \pm 0.02 \mathrm{~b}$ & -2.67 \\
$\mathbf{T}_{\mathbf{1}}$ & $86.13 \pm 9.13 \mathrm{c}$ & -13.80 & $16.46 \pm 2.32 \mathrm{a}$ & -7.13 & $0.185 \pm 0.04 \mathrm{ab}$ & -1.07 \\
$\mathbf{T}_{\mathbf{2}}$ & $87.27 \pm 9.17 \mathrm{c}$ & -10.11 & $16.35 \pm 2.21 \mathrm{a}$ & -7.19 & $0.183 \pm 0.03 \mathrm{~b}$ & -2.14 \\
$\mathbf{T}_{\mathbf{3}}$ & $88.04 \pm 9.17 \mathrm{~b}$ & -9.44 & $16.08 \pm 2.92 \mathrm{a}$ & -7.02 & $0.185 \pm 0.04 \mathrm{ab}$ & -1.07 \\
$\mathbf{T}_{\mathbf{4}}$ & $93.44 \pm 9.17 \mathrm{~b}$ & -6.40 & $16.66 \pm 2.32 \mathrm{a}$ & -7.13 & $0.180 \pm 0.04 \mathrm{c}$ & -3.74 \\
\hline
\end{tabular}

Data represented as mean $\pm \mathrm{SD}, \mathrm{n}=5$., Mean values in each column having different superscript $(\mathrm{a}, \mathrm{b}, \mathrm{c}, \mathrm{d}, \mathrm{e})$ are significantly different at $(\mathrm{p} \leq 0.05), \mathbf{T}_{1}$ : Yoghurt prepared by cow milk, $\mathbf{T}_{2}$ : Yoghurt prepared by blending cow milk: cow milk [1:1], $\mathbf{T}_{3}$ : Yoghurt prepared by blending cow milk: cow milk [3:1], $\mathbf{T}_{4}$ : Yoghurt prepared by blending cow milk: cow milk [6:1]

Changes of lipid profile concentrations of control and Hyperthyroidism Rats.

In (Table 3) studying changes of lipid profile among control and hyperthyroidism rats, a highly significant $(\mathrm{p}<0.05)$ increase in total cholesterol level was recorded in hyperthyroidism (+ve) group, when comparing with normal control group (-ve). Conversely, a high significant decrease in total cholesterol level was observed in treated groups feeding with enriched-chestnut yoghurts, when compared with untreated $(+v e)$ group. Serum triglycerides levels were also elevated in the hyperthyroidism (+ve) group by $(67.03 \%)$ when compared to normal control rats group. There was a significant decrease on TC, TG, LDL-c, total lipids and VLDL-c levels of treated groups that feeding 
on enriched-chestnut yoghurts with different premixes $\left(T_{1}, T_{2}, T_{3}\right.$ and $\left.T_{4}\right)$ when compared with hyperthyroidism rats $(+v e)(p<0.05)$. Meanwhile, there was a slightly increase on TC, TG, LDL-c and VLDL-c concentrations of treated groups that feeding on enriched-chestnut yoghurts especially premixes $\left(\mathrm{T}_{3}\right.$ and $\left.\mathrm{T}_{4}\right)$ by $(2.61,2.14 \% ; 5.76,4.49 \% ; 6.97,6.32 \%$ and $5.98,4.65 \%)$, respectively in comparison to normal control (-ve) group. these results confirmed with other finding of Jovanovic et al., (2017) who reported that chestnut extract reversed the alleviations of dyslipidemia in diabetic rats which reduced cholesterol and triglycerides values to control level. In addition, chestnut extract considered as rich source of tannins (Yıldiz et al., 2017), and tannins acted to hamper the development of hyperlipidemia by stopping the activity of pancreatic lipase and inhibiting energy intake in obese mice (Budriesi et al., 2018). In addition, Thyroid hormones dysfunction considered as major factors affected on lipogenesis and lipid metabolism (Gionfra et al., 2019).

Table 3: Changes of lipid profile concentration on hyperthyroidism rats groups in comparison to normal control group (-ve).

\begin{tabular}{|c|c|c|c|c|c|c|c|c|c|c|}
\hline Groups & $\begin{array}{c}\mathrm{TC} \\
\mathrm{mg} / \mathrm{dl}\end{array}$ & $\%$ & $\begin{array}{c}\mathrm{TG} \\
\mathrm{mg} / \mathrm{dl}\end{array}$ & $\%$ & $\begin{array}{l}\text { LDL-c } \\
\text { mg/dl }\end{array}$ & $\%$ & $\begin{array}{c}\text { HDL-c } \\
\text { mg/dl }\end{array}$ & $\%$ & $\begin{array}{c}\text { VLDL-c } \\
\mathrm{mg} / \mathrm{dl}\end{array}$ & $\%$ \\
\hline $\begin{array}{c}\text { Contr.(- } \\
\text { ve) }\end{array}$ & $\begin{array}{l}75.49 \pm \\
3.86 \mathrm{e}\end{array}$ & - & $45.16 \pm 3.28 \mathrm{c}$ & - & $\begin{array}{l}38.30 \pm \\
5.25 \mathrm{~d}\end{array}$ & - & $\begin{array}{c}28.35 \pm \\
4.71 \mathrm{a}\end{array}$ & - & $\begin{array}{l}9.03 \pm \\
1.457 \mathrm{e}\end{array}$ & - \\
\hline $\begin{array}{c}\text { Contr. } \\
(+\mathrm{ve})\end{array}$ & $\begin{array}{c}121.46 \pm \\
3.84 \mathrm{a}\end{array}$ & $\stackrel{+}{60.89}$ & $75.43 \pm 8.15 \mathrm{a}$ & $\stackrel{+}{67.03}$ & $\begin{array}{c}86.31 \pm \\
8.83 \mathrm{a}\end{array}$ & $\stackrel{+}{+}$ & $\begin{array}{c}19.47 \pm \\
1.18 \mathrm{e}\end{array}$ & $\stackrel{-}{31.32}$ & $\begin{array}{c}15.85 \pm \\
3.83 \mathrm{a}\end{array}$ & +75.52 \\
\hline PTU & $\begin{array}{c}76.48 \pm 4 \\
78 \mathrm{c}\end{array}$ & $\stackrel{+}{+}$ & $45.34 \pm 3.03 \mathrm{c}$ & $\stackrel{+}{+}$ & $\begin{array}{c}39.52 \pm \\
3.76 \mathrm{e}\end{array}$ & $\begin{array}{c}+ \\
3.185\end{array}$ & $\begin{array}{c}28.38 \pm \\
1.76 \mathrm{a}\end{array}$ & $\stackrel{+}{0.10}$ & $\begin{array}{c}9.09 \pm 1.61 \\
b c\end{array}$ & +0.66 \\
\hline$T_{1}$ & $\begin{array}{c}81.27 \pm 5 \\
52 \mathrm{~b}\end{array}$ & $\begin{array}{c}+ \\
7.65\end{array}$ & $51.19 \pm 6.46 b$ & $\stackrel{+}{+}$ & $\begin{array}{c}46.98 \pm \\
5.75 \mathrm{~b}\end{array}$ & $\begin{array}{c}+ \\
22.66\end{array}$ & $\begin{array}{l}24.03 \pm \\
0.37 \mathrm{c}\end{array}$ & - & $\begin{array}{c}10.29 \pm \\
1.62 \mathrm{~d}\end{array}$ & +13.95 \\
\hline $\mathbf{T}_{2}$ & $\begin{array}{c}80.14 \pm \\
3.65 \mathrm{~b}\end{array}$ & $\stackrel{+}{6.16}$ & $49.18 \pm 5.795 b$ & $\begin{array}{c}+ \\
8.90\end{array}$ & $\begin{array}{r}42.65 \pm \\
1.74 \mathrm{c}\end{array}$ & $\begin{array}{c}+ \\
11.36\end{array}$ & $\begin{array}{c}27.71 \\
\pm 2.36 \mathrm{~b}\end{array}$ & -2.26 & $\begin{array}{c}9.83 \pm 1.59 \\
b\end{array}$ & +8.86 \\
\hline $\mathbf{T}_{3}$ & $\begin{array}{l}77.46 \pm \\
4.65 \mathrm{c}\end{array}$ & $\begin{array}{c}+ \\
2.61\end{array}$ & $47.76 \pm 4.75 b$ & $\begin{array}{c}+ \\
5.76\end{array}$ & $\begin{array}{c}40.97 \pm \\
4.74 \mathrm{c}\end{array}$ & +6.97 & $\begin{array}{c}26.92 \pm \\
3.36 \mathrm{~b}\end{array}$ & -5.04 & $\begin{array}{c}9.57 \pm 1.59 \\
b\end{array}$ & +5.98 \\
\hline $\mathbf{T}_{4}$ & $\begin{array}{l}77.11 \pm \\
3.66 \mathrm{c}\end{array}$ & $\begin{array}{c}+ \\
2.14\end{array}$ & $47.19 \pm 4.75 b$ & $\begin{array}{c}+ \\
4.49\end{array}$ & $\begin{array}{c}40.72 \pm \\
4.74 \mathrm{c}\end{array}$ & +6.32 & $\begin{array}{c}26.96 \pm \\
2.36 \mathrm{~b}\end{array}$ & $\begin{array}{c}-4 . \\
90\end{array}$ & $\begin{array}{c}9.45 \pm 1.59 \\
b\end{array}$ & +4.65 \\
\hline
\end{tabular}

Values are expressed as mean $\pm S D ; n=5$, Mean values in each column having different superscript $(a, b, c, d, e)$ are significantly different at $(\mathrm{p} \leq 0.05), \mathbf{T}_{1}$ : Yoghurt prepared by cow milk, $\mathbf{T}_{2}$ : Yoghurt prepared by blending cow milk: cow milk [1:1], $\mathbf{T}_{3}$ : Yoghurt prepared by blending cow milk: cow milk [3:1], $\mathbf{T}_{4}$ : Yoghurt prepared by blending cow milk: cow milk [6:1]

\section{Changes of renal functions activities on normal and hyperthyroidism rats groups}

The hypothyroidism effects of enriched-chestnut yoghurts premixes on LT4-induced hyperthyroidism rats are shown in Table 4. In normal control (-ve) rats, serum uric acid levels were $1.51 \pm 0.42 \mathrm{mg} / \mathrm{dl}$. However in positive group (+ve), serum uric acid levels was decreased significantly to $0.99 \pm 0.62 \mathrm{mg} / \mathrm{dl}$ (p $<0.05$ ). The serum uric acid levels of hyperthyroidism rats treated with two 
premixes of yoghurts which prepared with chestnut by cow milk at percent $3: 1$ and $6: 1$ were slightly increased by $19.20 \%$ and $15,89 \%$ compared with normal group (-ve). During the 4 week post treatment period with the different premixes of enriched yoghurts with chestnut, renal function gradually improved, but not uniformly (Table 4). These results similar to investigation of Jovanovic et al., (2017) who reported that chestnut extract reversed the alleviations of urea nitrogen concentration in diabetic rats to control group level. Thyroid hormones are necessary for growth and development of renal and for the maintenance of water and electrolyte homeostasis which affected by hyperthyroidism condition. On the other hand, the kidney has a key role in the synthesis, metabolism, elimination and secretion of thyroid hormones (Kannan et al., 2017). Meanwhile, Srivastava et al., (2018) reported that renal dysfunction is associated with hypothyroidism.

Table 4: Changes of renal functions activities on hyperthyroidism rats groups in comparison to normal control group (-ve).

\begin{tabular}{cccccccc}
\hline Groups & $\begin{array}{c}\text { Uric acid } \\
\mathbf{m g} / \mathbf{d l}\end{array}$ & $\mathbf{\%}$ & $\begin{array}{c}\text { Creatinine } \\
\mathbf{m g} / \mathbf{d l}\end{array}$ & $\mathbf{\%}$ & $\begin{array}{c}\text { Urea Nitrogen } \\
\mathbf{m g} / \mathbf{d l}\end{array}$ & $\%$ \\
\hline Contr.(-ve) & $1.51 \pm 0.42 \mathrm{~d}$ & - & $1.34 \pm 0.54 \mathrm{~d}$ & - & $38.99 \pm 2.91 \mathrm{~d}$ & - \\
Contr. (+ve) & $0.99 \pm 0.62 \mathrm{a}$ & -34.44 & $3.91 \pm 0.47 \mathrm{a}$ & +191.79 & $52.96 \pm 3.57 \mathrm{a}$ & +35.83 \\
LT4 + PTU & $1.62 \pm 0.14 \mathrm{c}$ & +7.28 & $1.55 \pm 0.13 \mathrm{c}$ & +15.67 & $36.70 \pm 2.39 \mathrm{c}$ & -5.87 \\
& & & & & & \\
$\mathbf{T}_{\mathbf{1}}$ & $1.91 \pm 0.16 \mathrm{~b}$ & +26.49 & $2.07 \pm 0.17 \mathrm{~b}$ & +54.48 & $40.39 \pm 4.48 \mathrm{~b}$ & +3.59 \\
$\mathbf{T}_{\mathbf{2}}$ & $1.84 \pm 0.80 \mathrm{~b}$ & +21.85 & $2.10 \pm 0.25 \mathrm{~b}$ & +56.72 & $40.21 \pm 3.38 \mathrm{~b}$ & +3.13 \\
$\mathbf{T}_{\mathbf{3}}$ & $1.80 \pm 0.70 \mathrm{~b}$ & +19.20 & $1.74 \pm 0.25 \mathrm{c}$ & +29.85 & $37.76 \pm 3.38 \mathrm{c}$ & -3.15 \\
$\mathbf{T}_{\mathbf{4}}$ & $1.75 \pm 0.60 \mathrm{~b}$ & +15.89 & $1.64 \pm 0.25 \mathrm{c}$ & +22.39 & $37.21 \pm 3.38 \mathrm{c}$ & -4.56 \\
\hline
\end{tabular}

Data represented as mean $\pm \mathrm{SD}, \mathrm{n}=5$., Mean values in each column having different superscript $(\mathrm{a}, \mathrm{b}, \mathrm{c}, \mathrm{d}, \mathrm{e})$ are significantly different at $(\mathrm{p} \leq 0.05)$, . $\mathbf{T}_{1}$ : Yoghurt prepared by cow milk, $\mathbf{T}_{2}$ : Yoghurt prepared by blending cow milk: cow milk [1:1], $\mathbf{T}_{3}$ : Yoghurt prepared by blending cow milk: cow milk [3:1], $\mathbf{T}_{4}$ : Yoghurt prepared by blending cow milk: cow milk [6:1].

\section{Changes of AST and ALT activities on normal and hyperthyroidism rats groups}

With regard to liver function, LT4 led to a remarkable increase in serum AST and ALT levels in positive control (+ve) group as comparing with normal control group $(-v e)(p<0.05)$. Feeding on enriched-chestnut yoghurt with different premixes decreased $(\mathrm{p}<0.05)$ activities of AST and ALT levels of hyperthyroidism rats near to the level of the control (-ve). Though, the significant elevation $(\mathrm{p}<0.05)$ witnessed in AST and ALT levels of hyperthyroidism rats (Table 5 and Figure 1), which reduced by consumption of enriched-chestnut yoghurt with different premixes $\left(T_{2}\right.$ and $T_{4}$ followed $T_{3}$ and $\left.\mathrm{T}_{1}\right)$ that near to the normal control that recorded $(46.82 \pm 3.02,46.82 \pm 3.12$, $47.08 \pm 4.13$ and $50.08 \pm 4.28$ vr $84.07 \pm 5.58 \mathrm{U} / \mathrm{L}$ ). The liver damages accompanied by thyroid hormones dysfunction regardless of hyperthyroidism and alleviations in activities liver enzymes associated with oxidative stress induced by hyperthyroidism (Kim et al., 2012). Furthermore, hyperthyroidism has a major role on liver functions (Gionfra et al., 2019). In addition, 
Jovanovic et al., (2017) reported that administration of chestnut extract to diabetic rats caused a reduction on ALT concentration equally to value of normal control group and they linked its action to the systemic antioxidant effects of chestnut extract.

Table 5: Changes of AST and ALT activities on hyperthyroidism rats groups in comparison to normal control group (-ve).

\begin{tabular}{ccccc}
\hline Groups & $\begin{array}{c}\text { AST } \\
(\mathbf{U} / \mathbf{L})\end{array}$ & $\mathbf{\%}$ & $\begin{array}{c}\text { ALT } \\
(\mathbf{U} / \mathbf{L})\end{array}$ & $\%$ \\
\hline Contr.(-ve) & $43.82 \pm 2.11 \mathrm{~d}$ & - & $22.51 \pm 1.78 \mathrm{~d}$ & - \\
Contr. (+ve) & $84.07 \pm 5.58 \mathrm{a}$ & +91.85 & $46.36 \pm 3.27 \mathrm{a}$ & +105.95 \\
LT4 + PTU & $42.86 \pm 2.75 \mathrm{~d}$ & -2.19 & $22.46 \pm 2.13 \mathrm{~d}$ & -0.22 \\
& & & & \\
$\mathbf{T}_{\mathbf{1}}$ & $50.08 \pm 4.28 \mathrm{~b}$ & +14.28 & $27.99 \pm 3.43 \mathrm{~b}$ & +24.34 \\
$\mathbf{T}_{\mathbf{2}}$ & $46.82 \pm 3.02 \mathrm{c}$ & +6.84 & $26.73 \pm 2.14 \mathrm{~b}$ & +18.75 \\
$\mathbf{T}_{\mathbf{3}}$ & $47.08 \pm 4.13 \mathrm{c}$ & +7.44 & $25.13 \pm 3.43 \mathrm{c}$ & +11.64 \\
$\mathbf{T}_{\mathbf{4}}$ & $46.82 \pm 3.12 \mathrm{c}$ & +6.84 & $24.53 \pm 2.14 \mathrm{c}$ & +8.97 \\
\hline
\end{tabular}

Data represented as mean $\pm \mathrm{SD}, \mathrm{n}=5$., Mean values in each column having different superscript (a, b, c, d ,e) are significantly different at $(\mathrm{p} \leq 0.05), . \mathbf{T}_{1}$ : Yoghurt prepared by cow milk, $\mathbf{T}_{2}$ : Yoghurt prepared by blending cow milk: cow milk [1:1], $\mathbf{T}_{3}$ : Yoghurt prepared by blending cow milk: cow milk [3:1], $\mathbf{T}_{4}$ : Yoghurt prepared by blending cow milk: cow milk [6:1].

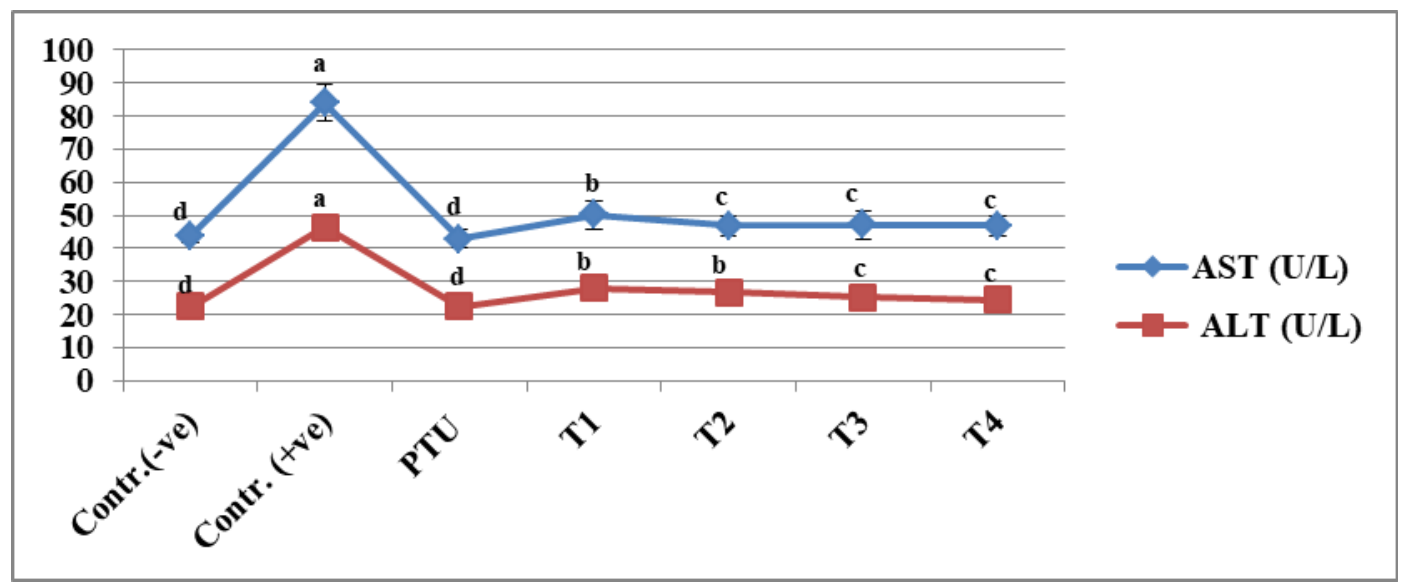

Figure 1: Changes of AST and ALT activities on normal and hyperthyroidism rats groups, Data represented as mean $\pm \mathrm{SD}, \mathrm{n}=5$., Mean values in each bar having different superscript ( $\mathrm{a}, \mathrm{b}, \mathrm{c}, \mathrm{d}, \mathrm{e})$ are significantly different at $(\mathrm{p} \leq 0.05)$, . $\mathbf{T}_{1}$ : Yoghurt prepared by cow milk, $\mathbf{T}_{2}$ : Yoghurt prepared by blending cow milk: cow milk [1:1], $\mathbf{T}_{3}$ : Yoghurt prepared by blending cow milk: cow milk [3:1], $\mathbf{T}_{4}$ : Yoghurt prepared by blending cow milk: cow milk [6:1]

\section{Changes of Triiodothyronine, Thyroxine and TSH activities on normal and hyperthyroidism rats groups}

Table (6) showed changes in serum levels of Triiodothyronine, Thyroxine and TSH among different groups. Hyperthyroidism simply defined as increases of serum Triiodothyronine and Thyroxine with decrease of serum 
TSH, a pituitary hormone that regulated thyroid functions (Kim et al., 2012). As expectation, in the positive control group (LT4), there was a significant increase in serum level of Triiodothyronine $(6.82 \pm 2.01, p<0.05)$ and Thyroxine $(17.33 \pm 4.55, p<0.05)$, but, a significant decrease in serum level of TSH $(2.84 \pm 0.16, p<0.05)$, in comparison to that in the normal control group $(3.02 \pm 1.7),(10.17 \pm 6.75)$ and $(5.03 \pm 0.32)$ respectively. Feeding on enrichedchestnut yoghurt treatment $T_{3}$ and $T_{4}$ that containing premixes chestnut on yoghurt by cow milk at percent (3:1 and 1:1 respectively) significantly reduced Triiodothyronine level and Thyroxine in the $\mathrm{T}_{4}$ group $(3.30 \pm 1.2$ and $10.43 \pm 0.70 \mathrm{ng} / \mathrm{dl}, P<0.05)$ and in the $\mathrm{T}_{3}$ group $(4.41 \pm 0.12$ and $10.59 \pm 0.70$ $\mathrm{ng} / \mathrm{dl}, P<0.05)$ compared to hyperthyroidism control group $(+\mathrm{ve})$, also comparing these groups with Control group, there are an increase in the activities of T3 and T4 by 46.03 and $9.27 \%$ respectively. Serum TSH levels in the hyperthyroidism control group $(2.84 \pm 0.16 \mu \mathrm{IU} / \mathrm{ml})$ were significantly lowered compared to the normal group $(5.03 \pm 0.32 \mu \mathrm{IU} / \mathrm{ml}, P<0.05)$. Thyroid stimulating hormone (TSH) considered as the main hormone that activated thyroid gland to produce thyroxine T3 and T4 which trigger the metabolism of various every tissue in the body (Kim and Lee 2019). Administration of enriched-chestnut yoghurt premixes with cow milk at percent $(3: 1$ and $1: 1)$ significantly improved TSH levels in the $\mathrm{T}_{3}$ and $\mathrm{T}_{4}$ groups $(4.98 \pm 0.21$ and $5.12 \pm 0.32 \mu \mathrm{IU} / \mathrm{ml}, P<0.05)$ compared to the normal control group. Meanwhile, there was nonsignificant of PTU treated group and $T_{3}$ and $T_{4}$ groups at levels of Thyroxine and TSH. These results were confirmed by Park et al., (2016) who found that PTU administration ameliorated hyperthyroidism reducing T4 and T3, and increasing both TSH (Table 6 and Figure 2) .

In this study serum Triiodothyronine and Thyroxine levels increased in LT4- receiving rats, and according to literature of Salehi et al., (2020) as they reported that herbal plants enhance thyroid function. So, consumption of enriched-chestnut yoghurt treatments $T_{3}$ and $T_{4}$ withstand against this increase in Triiodothyronine and Thyroxine concentrations. At the same time, these results are considered as direct evidences that enriched-chestnut yoghurt with different premixes have favorable ameliorating effect on the hyperthyroidisms and related complications induced by LT4 through systemic antioxidant effects (Pandey et al., 2018), such as and tannins that regulate thyroid function by way of their general characters of anti-oxidation and inflammatory inhibition (Yıldız et al., 2017). 
Table 6: Changes of Triiodothyronine, Thyroxine and TSH concentration on hyperthyroidism rats groups in comparison to normal control group (-ve).

\begin{tabular}{cccccccc}
\hline Groups & $\begin{array}{r}\text { Triiodothyronine } \\
\text { T3 }\end{array}$ & (ng/d) & \% & $\begin{array}{c}\text { Thyroxine T4 } \\
\text { (ng/dl) }\end{array}$ & $\begin{array}{c}\text { TSH } \\
\text { (uIU/ml) }\end{array}$ & \% \\
\hline Contr.(-ve) & $3.02 \pm 1.7 \mathrm{c}$ & - & $10.17 \pm 6.75 \mathrm{c}$ & - & $5.03 \pm 0.32 \mathrm{a}$ & - \\
Contr. (+ve) & $6.82 \pm 2.01 \mathrm{a}$ & +125.83 & $17.33 \pm 4.55 \mathrm{a}$ & +70.40 & $2.84 \pm 0.16 \mathrm{~d}$ & -43.54 \\
PTU & $3.32 \pm 0.23 \mathrm{c}$ & +9.93 & $10.02 \pm 3.11 \mathrm{c}$ & -1.47 & $4.98 \pm 0.21 \mathrm{~b}$ & -0.99 \\
T1 & $5.96 \pm 0.03 \mathrm{a}$ & +97.35 & $11.15 \pm 3.78 \mathrm{~b}$ & +9.63 & $3.65 \pm 0.16 \mathrm{c}$ & -27.43 \\
T2 & $4.81 \pm 0.11 \mathrm{~b}$ & +44.88 & $10.89 \pm 3.00 \mathrm{c}$ & +7.08 & $4.47 \pm 0.11 \mathrm{~b}$ & -11.13 \\
T3 & $4.41 \pm 0.12 \mathrm{~b}$ & +46.03 & $10.59 \pm 3.11 \mathrm{c}$ & +4.13 & $4.98 \pm 0.21 \mathrm{~b}$ & -0.99 \\
T4 & $3.30 \pm 1.2 \mathrm{c}$ & +9.27 & $10.43 \pm 0.70 \mathrm{c}$ & +2.55 & $5.12 \pm 0.32 \mathrm{a}$ & +1.79 \\
\hline
\end{tabular}

Values are expressed as mean $\pm \mathrm{SD} ; \mathrm{n}=5$, Mean values in each column having different superscript $(\mathrm{a}, \mathrm{b}$, $\mathrm{c}, \mathrm{d}, \mathrm{e})$ are significantly different at $(\mathrm{p} \leq 0.05), \mathbf{T}_{1}$ : Yoghurt prepared by cow milk, $\mathbf{T}_{2}$ : Yoghurt prepared by blending cow milk: cow milk [1:1], $\mathbf{T}_{3}$ : Yoghurt prepared by blending cow milk: cow milk [3:1], $\mathbf{T}_{4}$ : Yoghurt prepared by blending cow milk: cow milk [6:1]

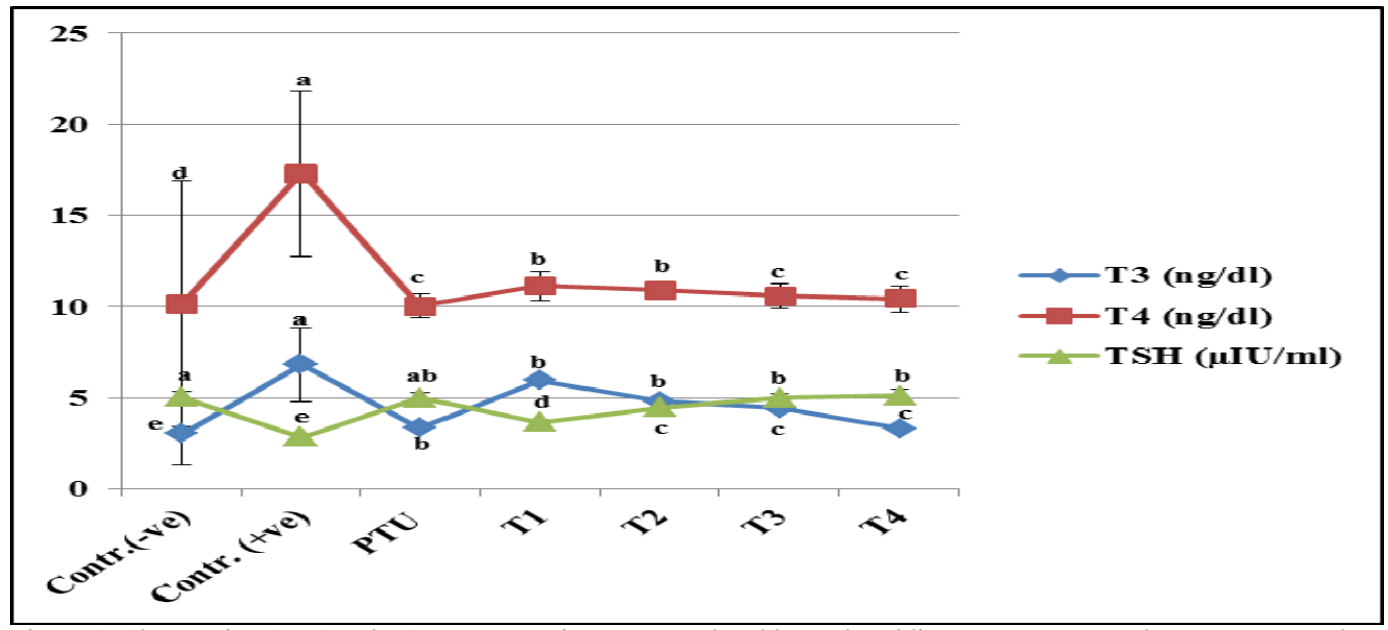

Figure 2: Changes in T3, T4 and TSH concentration on control and hyperthyroidism rats groups, Values are expressed as mean $\pm \mathrm{SD} ; \mathrm{n}=5$, Mean values in each bars having different superscript (a, b, c, d ,e) are significantly different at $(\mathrm{p} \leq 0.05), \mathbf{T}_{1}$ : Yoghurt prepared by cow milk, $\mathbf{T}_{2}$ : Yoghurt prepared by blending cow milk: cow milk [1:1], $\mathbf{T}_{3}$ : Yoghurt prepared by blending cow milk: cow milk [3:1], $\mathbf{T}_{4}$ : Yoghurt prepared by blending cow milk: cow milk [6:1].

\section{Conclusion}

Based on above results, it concluded that LT4 induced hypothyroidism and related biomarkers of lipid profile, renal and liver activities inhibited by oral treatment of enriched-chestnut yoghurt with different premixes especially treatment $T_{3}$ and $T_{4}$. In addition, these premixes enhanced thyroid hormones as direct evidences that blending chestnut on yoghurt with different premixes improved and have favorable amelioration influence on the hyperthyroidism and related damages in organs in LT4-induced hyperthyroidism on rats. Further studies on mechanism and other linked factors are needed. 


\section{References}

A.A.C.C., 2000. American Association of Cereal Chemistry 12th Ed. Pub. By American Association of Cereal Chemistry.Univ. of Fam. St. Paul. Minnesota. USA.

Bartels, H., Bohemer, M., and Heirli, C., 1972. Colorimetric kinetic method of creatinine. Clin. Chem. Acta., 37: 193.

Bhowmich, S.K., Dasari, G., Leavens, K.L. and Rettig, K.R., 2007. The prevalence of elevated serum thyroid-stimulating horomone in childhood/adolescent obesity and of autoimmune thyroid diseases in a subgroup. J. of the National Medical Association. 99: 773-776.

Budriesi, R., Vivarelli, F., Canistro, D., Aldini, R., Marquillas, C.B., Corazza, I., Fato, R., Cirillo, S., Bergamini, C., D'Errico, A., Bolchi, C., Cevenini, M., Degiovanni, A., Frosini, M., Camarda, L., Chiarini, A., and Micucci, M., 2018. Liver and intestinal protective effects of Castanea sativa Mill. bark extract in high-fat diet rats. PLoS ONE 13(8): e0201540.

Caraway, W. T., 1955. Determination of uric acid in serum by a carbonate method. Amer. J. clin. Path., 25, 840.

Chiarini, A., Micucci, M., Malaguti, M. et al., 2013. "Sweet chestnut (Castanea sativa Mill.) bark extract: cardiovascular activity and myocyte protection against oxidative damage," Oxidative Medicine and Cellular Longevity, Article ID 471790, 10 pages, 2013.

Collins, J.L., Ebah, C.B., Mount, J.R., Demott, M.J. and Draughon, F.A., 1991. Production and evaluation of milk-sweet potato mixtures fermented with yoghurt bacteria. J. of Food Sci. 56:685-688.

Davidson, B., Soodak, M., Neary, J.T., Strout, H.V., Kieffer, J.D., Mover, H. and Maloof, F., 1978. The irreversible inactivation of thyroid peroxidase by methylmercaptoimidazole, thiouracil, and propylthiouracil in vitro and its relationship to in vivo findings. Endocrinology, 103: 871-882.

De Leo, S., Lee, S. Y., and Braverman, L. E., 2016. "Hyperthyroidism," $2 e$ Lancet, 388(10047): 906-918.

Fossati, P., and Prencipel, L., 1982. Determination of triglycerides,Bicon Diagnostics, made in Germany. Clinical Chemistry; 28: 2077-2078.

Gao, H.X., Yu, Z.L., He, Q., Tang, S.H., and Zeng, W.C., 2018. A potentially functional yogurt co-fermentation with Gnaphalium affine. LWT-Food Sci Technol 91:423-430.

Gionfra, F., De Vito, P., Pallottini, V.,Lin, H.Y, Davis, P.J, Pedersen, J.Z, Incerpi, S. 2019 .The Role of Thyroid Hormones in Hepatocyte Proliferation and Liver Cancer. Front Endocrinol (Lausanne). 10:532. 
Granato, D., Nunes, D.S., and Barba, F.J., 2017. An integrated strategy between food chemistry, biology, nutrition, pharmacology, and statistics in the development of functional foods: A proposal. Trends Food Sci. Technol. 62, 13-22.

Han, B.H., Park, M.H.,Han, Y.N. , and Shin, S.C., 1984. Studies on the antioxidant components of Korean ginseng Antifatigue active components. Yakhakhoe Chi , 28, 231-235.

Jovanović, J.A., Mihailović, M., Uskoković, A.S., Grdović, N, Dinić, S, Poznanović ,G, Mujić, I, Vidaković, M. 2017. Evaluation of the Antioxidant and Antiglycation Effects of Lactarius deterrimus and Castanea sativa Extracts on Hepatorenal Injury in Streptozotocin-Induced Diabetic Rats. Front Pharmacol. 8:793.

Jukic, H., and trutic, N., 2014. Antioxidant and antibacterial properties of castanea sativa mill catkins extracts. International society for horticultural science, Institute of Nutrition, Adhoc Wiling Committee on reformulation of the AIN 93. Rodent Diet. J. Nutri.; 123: 1939-51.

Kannan, A., Sriramakrishnan, V., Kannan, B., and Anandan, H., 2017. Thyroid Function Abnormalities in Patients with Chronic Kidney Disease - A Prospective Study International Journal of Scientific Study | July 2017 | Vol 5 | Issue 4.

Khaled, A.A., and Abul-Fadle, M.D., 2017. Serum Irisin Level Changes after Propylthiouracil Treatment of L-Thyroxine Induced Hyperthyroidism in Rats Med. J. Cairo Univ., 85(4): 1515-1523.

Kim, M., and Lee, B.C., 2019. Therapeutic Effect of Scutellaria baicalensis on L-Thyroxine-Induced Hyperthyroidism Rats, Evidence-Based Complementary and Alternative Medicine, Article ID 3239649, 8 pages.

Kim, S.M., Kim, S.C., Chung, I.K. Cheon, W.H., and Ku. S.K., 2012. Antioxidant and Protective Effects of Bupleurum falcatum on the 1Thyroxine-Induced Hyperthyroidism in Rats. Evidence-Based Complementary and Alternative Medicine Article ID 578497, 12 pages

Larsen, P.R., 1972. Triiodothyonine: Review of recent studies of its physiology and pathophysiolog in man. Metabolism. 21:1073-1092.

Lee, S.Y., Morr, C.V., and Gruber, V.A., 1990. Comparison of milk-based and soymilk-based yogurt. J. Food Sci. 55:532-536.

Lenzi, M., Malaguti, M., Cocchi, V., Hrelia, S., and Hrelia, P., 2017. Castanea sativa Mill. bark extract exhibits chemopreventive properties 
triggering extrinsic apoptotic pathway in Jurkat cells, BMC Complementary and Alternative Medicine 17:251.

Mohamed Barkallah, Mouna Dammak, and Ibtihel Louati 2017. Effect of Spirulina platensis fortification on physicochemical, textural, antioxidant and sensory properties of yogurt during fermentation and storage. Comprrev food Scif 1249-1251.

Muzaffar, S., and Maqbool, K., 2016. Physico-chemical characterization of sweet chestnut (castanea sativa mill) starch grown in temperate climate of Kashmir, India: Acta alimentaria. 45(2):258-267.

Oniszczuk , A., Widelska, G., Wójtowicz , A., Oniszczuk , T., Kulesza ,K.W., Dib, A., and Matwijczuk, A., 2019. Content of Phenolic Compounds and Antioxidant Activity of New Gluten-Free Pasta with the Addition of Chestnut Flour, Molecules 24, 2623.

Osundahunsi, O., Amosu,D., and Ifesan, B.O., 2007. Quality evaluation and acceptability of soy youhurt with different colours and fruit flavours. American. J. Food Techn. 2(4):273-280.

Ozcan. T., Yilmaz-Ersan, L., Akpinar-Bayizit, A., and Delikan, B., 2017. Antioxidant properties of probiotic fermented milk supplemented with chestnut flour (Castanea sativa Mill). J Food Process Preserv. 41:e13156.

Pandey, P.K., Sahiba, joshi, A.K., and juyal, D., 2018. Castenea Sativa MillA review on its phytochemical and pharmacological profile, The Pharma Innovation Journal 7(5): 94-96.

Park, S.I., et al. 2016. Therapeutic Effects of Blue Honeysuckle on Lesions of Hyperthyroidism in Rats. Am. J. Chin. Med., 44 (7): p. 1441-1456.

Raikos , V., Ni , H., Hayes, H., and Ranawana, V., 2019. Antioxidant Properties of a Yogurt Beverage Enriched with Salal (Gaultheria shallon) Berries and Blackcurrant (Ribes nigrum) Pomace during Cold Storage. Beverages 5, 2.

Reeves, P.G., Nielson, F.H. and Fahey, G.C., 1993. Final report of the American Institute of Nutrition, Adhoc Wiling Committee on reformulation of the AIN 93. Rodent Diet. J. Nutri.; 123: 1939-51

Reitman, S., and Frankel, S., 1957. Estimation of serum alanine and aspartate aminotransferases. Clin .Path. Am. J.; 28: 57-63.

Ríos-Prego, M., Luis Anibarro1 Paula and Sánchez-Sobrino. 2019. Relationship between thyroid dysfunction and body weight: a not so 
evident paradigm, International Journal of General Medicine 12 299304

Roeschlau, P.; Bernt, E. and Gruber, W. (1974): Enzymatic colorimetric test with lipid clearing factor (LCF) .J. Clin.Chem. \& Clin. Biochem., 12:403-408.

Salehi , B., Azzini , E., Zucca , P., Varoni ,E.M., V. Anil Kumar, N.; Dini, L.; Panzarini, E.; Rajkovic, J.; Valere Tsouh Fokou, P.; Peluso, I.; Prakash Mishra, A.; Nigam, M.; El Rayess, Y.; El Beyrouthy, M.; N. Setzer, W.; Polito, L.; Iriti, M.; Sureda, A.; Magdalena QuetglasLlabrés, M.; Martorell, M.; Martins, N.; Sharifi-Rad, M.; M. Estevinho, L.; Sharifi-Rad, J. 2020. Review Plant-Derived Bioactives and Oxidative Stress-Related Disorders: A Key Trend towards Healthy Aging and Longevity Promotion, Appl. Sci. 10, 947.

Santulli C, Janssen M, and Jeronimidis G. 2017. Partial replacement of Eglass fibres with flax fibres in composites and effect on falling weight impact performance. Mater Sci.;40:3581e5.

Schuurs, W.M., and Van Weeman, B.K., 1997. Review, enzymeimmunoassay Clin. Chem. Acta. 81:1-40.

Sengul, M., Erkaya, T., Sengul, M., and Yildiz, H. 2012. The effect of adding sour cherry pulp into yoghurt on the physicochemical properties, phenolic content and antioxidant activity during storage. Int J Dairy Technol 65:429-436.

Singh, H.,Thakur, S.N.,Wilson, I., Kishor, K., and Rai, B.S., 2017. Studies on quality parameters of bun incorporated with wheat flour water chestnut flour and soya flour. The Pharma Innovation Journal, 6(8): 119-124.

Srivastava, S., Rajput, J., Shrivastava, M., Chandra, R., Gupta, M., and Sharma, R.2018. Correlation of thyroid hormone profile with biochemical markers of renal function in patients with undialyzed chronic kidney disease. Indian J Endocr Metab 22:316-20.

Vandallen, D.B., 1997. Research methods and statistically analysis. Egyptian, Anglo Library Cairo, Egypt, 942-943.

Yadav, B.S., Yadav, R.B., Kumari, M., and Khatkar, B.S., 2014. Studies on suitability of wheat flour blends with sweet potato, colocasia and water chestnut flours for noodle making. Food Science and Technology, 57: 352-358.

Yıldız, S., Yılmaz, A., Can, Z., Kılıç, C., and Yıldız, C., 2017. Total phenolic, flavonoid, tannin contents and antioxidant properties of Pleurotus ostreatus and pleurotus citrinopileatus cultivated on various Sawdust. GIDA, 42 (3): 315-323. 


\section{الملخص}

تقييم التأثير المحتمل للزيادي المدعم بأبو فروة على الفئران المصابة بزيادة

\section{نشاط الغدة الدرقية الناتج عن حقنها بهرمون الغدة الدرقية}

أن تزايد الاهتمام بالطب البديل والتكميلي ادي الى استخدام النباتات الطبية بسبب التكلفة الهنخفضة وقلة الآثار السلبية له. أجريت هذه الدراسة لتقييم التأثير الدضاد لزيادة نشاط الغدة الدرقية بانتاج زبادي وظيفي مدعم بأبو فروة على الفئران التى تم حقنها بجرعة ليفوثيروكسين (LT4). وتم تقسيم

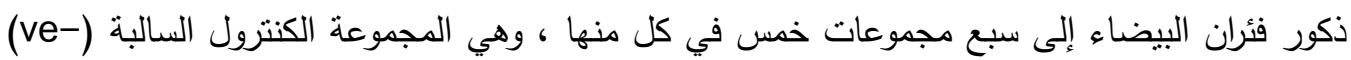

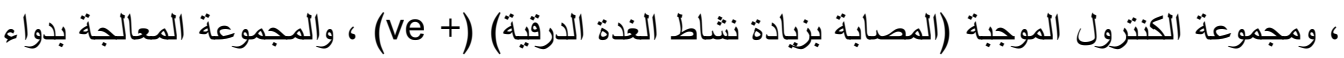

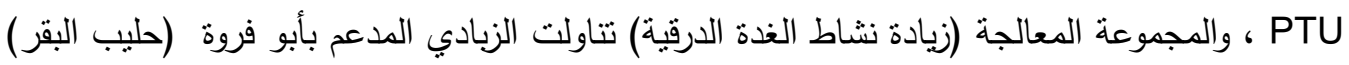

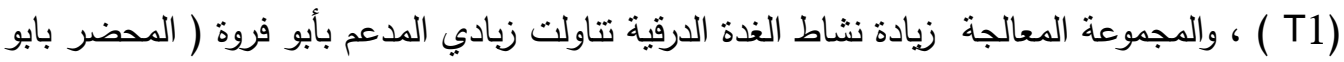
فروة : حليب البقر بنسبة [1: 1] (T2) ، ،ثم المجموعة المعالجة زيادة نشاط الغدة الدرقية تتاولت

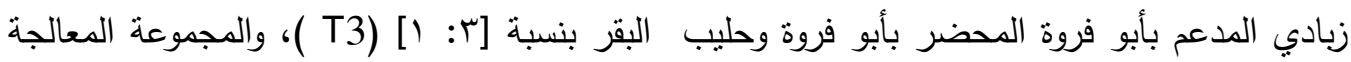

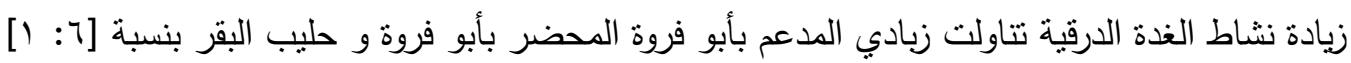

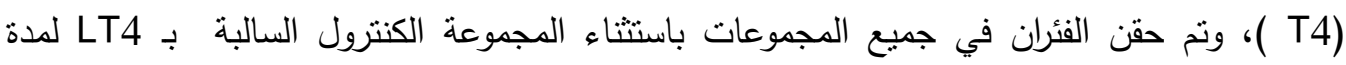
أسبوعين للحث على فرط نشاط الغدة الدرقية ـ ثم تم إعطاء كل علاج لمدة 7 أسابيع، ونم تحديد

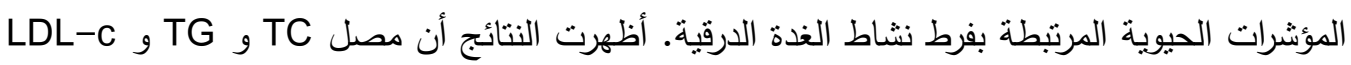

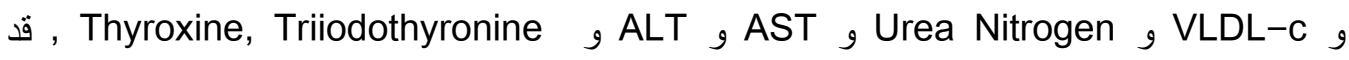
انخفض بشكل كبير في مجموعات (T3) و (T4) و الدواء مقارنة بمجموعة فرط نشاط الغدة الدرقية

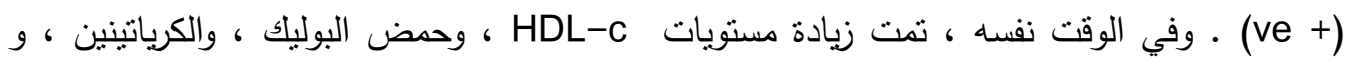

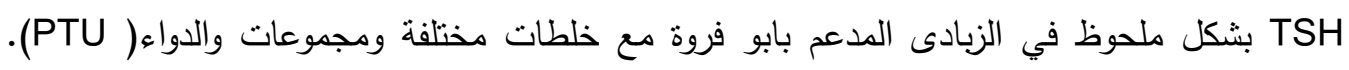

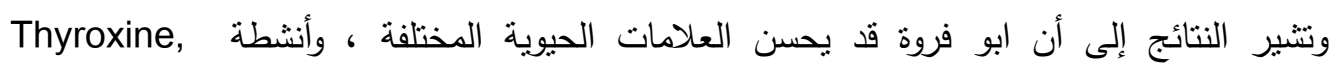
هم TSH وTriiodothyronine مع ابو فروة علاجًا بديلاً لفرط نشاط الغدة الدرقية. 